\title{
Gregor Gall
}

\section{Unions in Britain: Merely on the Margins or on the Cusp of a Comeback?**}

This paper examines the past, present and future trajectory of unions and the union movement in Britain to analyse whether collectively they remain on the margins of influence in the economy and society or whether, given and because of the crisis of neoliberalism, they may be on the cusp of a comeback. Diagnosis and prognosis are sobering such that a possibility rather than probability of a comeback is discussed. This task is carried out by specifying the dimensions and criteria for renewal and revitalisation across a range of indicators.

Key words: labor-management relations, trade unions, collective bargaining, Great Britain (JEL: J50, J51)

* Professor Gregor Gall, University of Hertfordshire, Hatfield AL10 9AB, Britain. E-mail: g.gall@herts.ac.uk.

** Article received: August 6, 2012

Revised version accepted after double blind review: October 22, 2012. 


\section{Introduction}

The (uncontested) election of Frances O'Grady to become the first ever female general secretary of the Trade Unions Congress (TUC) in its 144 year history presents an opportune moment to assess whether unions - and the wider union movement more generally - in Britain are continuing their position as being on the margins of the economy and society or, alternatively, whether they could be on the cusp of a something of a comeback in terms of their bargaining influence and political prowess. According to a number of informed commentators (e.g., Cochrane, 2012; Roberts, 2012), the potential for O'Grady to facilitate a comeback - defined as renewal and revitalisation across and throughout the unions in terms of bargaining influence, political prowess and organisational strength - is not just because O'Grady - as a woman - is now reflective of the dominant group in union membership and the workforce, namely, women. It is also because she has gained experience outside the TUC as a campaigning union officer, has a more distinct orientation upon the TUC being the head of the union movement constituted as a social movement and is more prepared to engage with social forces outside of the union movement in order to build alliances in civil society. In short, both her skills and perspectives as TUC leader are viewed as making the task of renewal and revitalisation in these terms possible (if not probable). While it is healthy scepticism to doubt whether the 'captain' of the proverbial oil tanker can alone turn around the 'ship' so quickly and easily given the existing and embedded trajectory of the union movement, the sense in which O'Grady could become a facilitator of change - rather than creator of change - is a more serious and robust proposition, even though the power to do so depends on the will and resource of the TUC- affiliated unions and developments external to those unions.

Consequently, the purpose of this article is to take the change of leadership of the TUC as both a heuristic point of departure and a mechanism by which to examine the past, present and future trajectory of the union movement in Britain. In essence, the overarching research question has three aspects to it: what has happened to the unions, what is happening to unions and what will happen to the unions? Carrying out this task is organised by essentially splitting the article into two sections, namely, retrospect (dealing the past and present) and prospect (dealing with the future). And although judging the past is a relatively easier task, judging the present and future is more fraught because without the benefit of hindsight a counter-factual approach must necessarily be deployed. However, using a standard set of robust criteria, informed by past experience, helps minimise the problems and challenges in doing so. Indeed, doing so provides a good guide as to what a comeback must constitute in order to genuinely be a 'comeback'. This means that returning to former days of heightened influence will be no mean feat to achieve. As will become clear in the article, unions are neither seen as innocent bystanders in their fate. Nor are they seen as masters of their own destiny either. To paraphrase Marx, unions make their own history but not necessarily in circumstances of their own choosing. Therefore, it is the balance the dialectic between environment and agency - that is crucial to establishing what latitude unions have to move from the margins to the cusp of a comeback. 
The primary means for establishing - and the analysing - the health and vitality of the union movement in these terms are the three, often closely linked, levels of membership, collective bargaining coverage and strike activity. The statistics for examining these three indices comes from data from the unions themselves and agencies of the state such as the Certification Office and Office of National Statistics (ONS). These aggregate data are suitable for the task of assessing of unions collectively put together as a union movement, with the TUC at their head as the singular peak organisation for the overwhelming majority of unions (which also have the overwhelming majority of total union membership). That said individual unions differ from each other in a number of regards concerning, inter alia, sector effects (labour and product markets), union histories and politics and the power of disruption. To attempt to build a picture up the way of the union movement from a consideration of individual unions would be not only beyond the scope of a single article but lead to a less tangible and productive outcome than using aggregate data. Nonetheless, the fruits of the aggregate approach can be usefully supplemented by sectoral and individual union studies.

Notwithstanding what rights in law individual workers and non-union members have, union membership is a good barometer of the standing and effectiveness of unions as collective actors in the employment relationship and wider society. All other things being equal, stronger and more credible unions will be in absolute and relative terms be large and stable, if not growing, unions. Similarly, and notwithstanding the free rider phenomenon, the extent of collective bargaining across the economy is another measure of union strength, utility and appeal - for the provision of the collective means to defend and advance terms and conditions of employment is the main reason for both membership joining and retention. Indeed, the extent of collective bargaining is an indicator of the labour market power of unions. Lastly, the preponderance of strike action is a good indication of the bargaining strength of unions and their disruptive capacity. Although in abstract terms, a low level of strikes may be indicative of union strength for the threat of striking may be sufficient to gain bargaining objectives or highly developed systems of centralised bargaining and corporatism may obviate the need for strikes and the threat of them, it is clear that in the current epoch in Britain this seldom applies. Thus, the ability to take strike action - notwithstanding the issue of effectiveness in gaining bargaining objectives and the cost incurred in doing so - is an appropriate way in which by which to gain a measure of union strength, especially where the resource of membership is applied to collective bargaining through collective mobilisation.

The significance of using these three measures, and viewing them in the way outlined above and below so that relatively straightforward quantitative dimensions can also be given a qualitative aspect too, is validated and magnified because of the nature of the governance of industrial relations within Britain. As a liberal market economy, the system is a decentralised one with minimal legal regulation. Consequently, employer behaviour in the employment relationship (and elsewhere) is little regulated. For example, there is little legal compulsion to recognise a union for collective bargaining, and workers have no right to strike in law (with striking being a breach of contract and only unions are accorded immunity in tort). By contrast, in many continental western 
European societies, workers have a much greater and more significant menu of legal rights, bargaining agreements are applied sectorally and workers have collective rights in the workplace in the form of works councils and works committees. (Indeed, if Britain existed as a coordinated market economy, the approach to examining these three indicators would be quite different, and they would be supplemented by measures on political exchange and corporatism) Although there are still considerable differences with governance of industrial relations system in the United States, Britain continues to face towards the Atlantic and not towards Europe in regard of employment and workers' rights. This is despite of the force of the social dimension to the European Union and because of the decision by consecutive Labour governments (1997-2010) to apply the principles and directives in an extremely minimalist way. The other significance of using the three aforementioned indicators is that, however imperfect they may be, reasonably robust time series data exists by which to track movements in each.

The approach to deploying these data is then to use them as both signifiers of institutions and processes. Unions are institutions in an organisational sense and comprise part of the furniture of industrial relations but they also embody the primary process by which workers seek to pursue their sectional and, sometimes, class interests in the workplace arena. The approach can be applied to collective bargaining whereby it has both institutional and processual features. However, merely using the indicators is insufficient so that they need to be supplemented by others so that the fundamental sources of union power are surveyed. Batstone (1988) identified these as ability to disrupt the production, distribution and exchange of goods and services, scarcity of labour and political influence. The political influence of unions can be exercised through a political party or directly upon government. In the case of Britain, political influence has most often taken the form of unions affiliating to the Labour Party but increasingly unions working with pressure groups and non-governmental organisations warrants attention. Allied to consideration of political influence are also those of ideological influence. The political centre of gravity of most unions ranges from socialism to social democracy but both have severely waned as a result of the rise of neo-liberalism. Neo-liberalism is hegemonic now not just in society and amongst government but within the workplace for human resource management (HRM) is the application of neo-liberalism in the workplace whereby it reinforces and extends employer power as an ideological form of control. By considering these five indicators (membership, collective bargaining, strikes, political influence, and ideological influence), a more rounded sense of the retrospect and prospect for unions in Britain can be ascertained.

For the reader in continental Europe or the United States, the case of Britain is a somewhat strange phenomenon. The regulation of the employment relationship and industrial relations in Britain has become neither completely Americanised (i.e., experience massive deregulation) despite a period of extended Thatcherism and Blairism, nor has it become more like the continental pattern as a result of membership of the European Union and its social dimension (i.e., maintenance of some considerable collective regulation or re-regulation). The rather idiosyncratic path of Britain reflects the contending pressures of global neo-liberalism placed upon a national state which still 
has a heritage of limited social democracy. In this sense, and despite the increasing colonisation of the European Union by neo-liberalism, Britain is still mid-way between the Atlantic and the European landmass. In general measures, this can be seen in terms of the indices of union membership, collective bargaining coverage and strike activity, with the United States at one end of the spectrum and many continental European countries at the other.

\section{Retrospect}

\section{Union membership: the dimensions of decline}

In the post-war period, the highpoint of union membership was in 1979-1980 of $13.5 \mathrm{~m}$ members, representing $55 \%$ density. This came at the end of a period characterised by economic growth, government and state support for 'responsible' unionism, the hegemony of pluralism amongst major employers, a rise in the level of strike activity and the development of workplace unionism in the public sector. Since then, the trend has been unremittingly downwards even though the pace of decline slackened off, and there were a couple of years of absolute growth at the end of the 1990s and into the 2000s (see Table 1). However, an expanding labour force meant that even those years did not record growth in density. In retrospect, such a picture is a trebly disappointing one for the unions given a) the overall growth in employment; b) the growth in public sector employment where union density is the highest and employer support for unions greater; and c) the spread of 'union organising' (see later) and the devotion of considerable resources to it.

Economic growth from the mid-1990s to the late 2000s provided the potential, conducive basis for membership growth while a relatively more favourable government (compared to 1979-1997) was also in power from 1997-2010. But these factors may, thus, be seen as necessary without being sufficient to facilitate membership growth. Consequently, the deployment of 'union organising' from the mid-1990s onwards (see Gall, 2010) was a necessary requirement to take advantage of the more favourable environment. However, as a result of qualitative and quantitative inadequacies (Gall \& Fiorito, 2011), 'union organising' did not prove to be the key to unlock the door towards sustained and significant membership (even if it may have prevented further and more significant retrenchment). To coin a phrase, unions in this regard were 'running very fast merely to stand still'. However, a number of unions did record significant growth (such as the specialist and occupational teaching and nursing unions) while most of the general and industrial unions, like Unite and its predecessors, recorded huge decline. In the private sector, density has fallen from $21.4 \%$ in 1995 to $14.1 \%$ in 2011 while density in the public sector has fallen from $61.3 \%$ to $56.5 \%$ over the same period (Brownlie, 2012 and for subsequent statistics). Some areas like hotels, shops and restaurants have become almost 'union free' with density falling from $7.9 \%$ to $3.6 \%$ over the same period. As worryingly, the age profile of union members is now increasingly old. In 1995, 6.4\% of 16 to 19 year olds were union members. By 2011, this had dropped to $3.1 \%$. The corresponding figures for 20 to 24 year olds were $19.3 \%$ to $11.4 \%$ and $28.4 \%$ to $18.2 \%$ for 25 to 29 year olds. Meantime, the density for 65 to 69 year olds has risen from $7.5 \%$ to $14.1 \%$ in the same period. Not only has union membership often been seen as too 'male, pale [white] and stale [passive]' but it is 
also becoming 'frail', i.e., elderly. Finally, the rise of the 'never member' has become very pronounced. In 1985-1986, those who had never been a member of a union comprised 22\% of employees. By 2006-2008, this had risen to 52\% (Bryson \& Forth, 2010, pp. 9-10).

And while the quantitative dimensions of the decline in union membership are not the 'be all and end all', it is also evident that the qualitative dimension of union membership has also atrophied. Thus, union members are more atomised from each other than before as a result of reduced participation rates so that unions have become less coherent and effective collective organisations which crucially depend upon the voluntary and volunteer actions of their members. Moreover, the basis on which workers are recruited to many unions does not stress activity and involvement - rather that they are more like passive consumers buying a service for a rainy day. Probably more important is that the milieu of workplace union activists has continued to shrink, from around 300,000 in the 1980 s to around 100,000 in the 2000s according to Bryson and Forth (2010, p. 12) or 500,000 in 1979 to 230,000 by 2003 (Gall, 2005). Consequently, much representative and bargaining work does not get done whilst that which is carried out is the responsibility of a smaller number of activists leading to burnout and turnover.

Put together, these quantitative and qualitative dimensions together do not suggest that unions have quite passed the point of no return or no recovery. But for recovery and return to take place, the key process is for existing members, activists and union resources to be deployed to recruit, train and create new members, activists and resources. The smaller the existing numbers and resources get, the harder it becomes to do so. This is the context in which to judge the fate of the application of 'union organising', where members are urged and trained to become active in resolving their own grievances rather than being serviced by paid (external) officers of the union. Thus, aimed at using the centralised resources (officers and finance) of national unions to support targeted campaigns to recruit and retain members and make them largely self-sufficient so that the resources can then be applied elsewhere in order to create a virtuous, upward spiral, 'union organising' since the mid-1990s has not been particularly effective judged by the aforementioned data on membership and activism. No doubt the situation would have been worse without the intervention and agency of 'union organising' and it is also clear that 'union organising' has not got in the way of some other and better strategy emerging (Gall \& Fiorito, 2010). Yet, this still does not mean that 'union organising' has been able to make the necessary positive, productive and significant contribution. There are various possible reasons for this, extending from insufficient resources given over to it, poor application and bastardisation to 'union organising' as a grassroots practice not being up to the scale of the task facing unions (see also Daniels, 2009; McIlroy \& Daniels, 2009a). Indeed, the only unions which have been able and willing to resource their application of 'union organising' to a critical and sustained degree have been Unite, the general union, and USDAW, the retail workers' union. The former has still suffered immense membership loss while the other has grown to be the fourth biggest union, helped by a small number of very large and supportive employers who are happy with the nonadversarial stance of USDAW. Overall, the disparity between the two unions testifies 
to the different sectors in which the two unions organise - the former being mostly in the declining manufacturing sector and the latter being mostly in the growing retail sector. In similar terms, the teaching unions - which have also applied 'union organising' - have experienced the greatest growth of any set of unions but this has not been sufficient to offset overall impact of the decline of the more general unions. Finally, and notwithstanding that a small number of unions like Unite and USDAW have their own academies, the commitment of unions to 'union organising' may now be waning judged by the declining cohorts passing through the TUC's Organising Academy each year since it was established in 1998. Set up and initially led by O'Grady, the Academy was designed to facilitate change not by training all such organisers for all affiliated unions but by training those who would lead by example and proselytise for 'union organising' once working with affiliated unions.

Table 1: Union density, recognition coverage and bargaining coverage, 1993-2011

\begin{tabular}{|c|c|c|c|c|c|}
\hline Year & $\begin{array}{c}\text { TUC } \\
\text { membership }\end{array}$ & $\begin{array}{c}\text { Total union } \\
\text { membership (CO) }\end{array}$ & $\begin{array}{c}\text { Total union } \\
\text { membership (LFS) }\end{array}$ & $\begin{array}{c}\text { Union } \\
\text { density (LFS) }\end{array}$ & $\begin{array}{l}\text { Collective bargaining } \\
\text { density (LFS) }\end{array}$ \\
\hline 1993 & $\mathrm{n} / \mathrm{a}$ & $9.048 \mathrm{~m}$ & $7.909 \mathrm{~m}$ & $35.1 \%$ & $\mathrm{n} / \mathrm{a}$ \\
\hline 1994 & $\mathrm{n} / \mathrm{a}$ & $8.700 \mathrm{~m}$ & $7.533 \mathrm{~m}$ & $33.6 \%$ & $\mathrm{n} / \mathrm{a}$ \\
\hline 1995 & $6.898 \mathrm{~m}$ & $8.278 \mathrm{~m}$ & $7.275 \mathrm{~m}$ & $32.4 \%$ & $\mathrm{n} / \mathrm{a}$ \\
\hline 1996 & $6.799 \mathrm{~m}$ & $8.089 \mathrm{~m}$ & $7.215 \mathrm{~m}$ & $31.3 \%$ & $\mathrm{n} / \mathrm{a}$ \\
\hline 1997 & $6.756 \mathrm{~m}$ & $7.938 \mathrm{~m}$ & $7.117 \mathrm{~m}$ & $30.2 \%$ & $37.0 \%$ \\
\hline 1998 & $6.754 \mathrm{~m}$ & $7.801 \mathrm{~m}$ & $7.107 \mathrm{~m}$ & $29.6 \%$ & $36.0 \%$ \\
\hline 1999 & $6.746 \mathrm{~m}$ & $7.852 \mathrm{~m}$ & $6.981 \mathrm{~m}$ & $29.7 \%$ & $35.4 \%$ \\
\hline 2000 & $6.816 \mathrm{~m}$ & $7.898 \mathrm{~m}$ & $7.120 \mathrm{~m}$ & $29.8 \%$ & $36.1 \%$ \\
\hline 2001 & $6.721 \mathrm{~m}$ & $7.779 \mathrm{~m}$ & $7.045 \mathrm{~m}$ & $29.3 \%$ & $35.5 \%$ \\
\hline 2002 & $6.685 \mathrm{~m}$ & $7.751 \mathrm{~m}$ & $7.023 \mathrm{~m}$ & $28.8 \%$ & $35.2 \%$ \\
\hline 2003 & $6.690 \mathrm{~m}$ & $7.736 \mathrm{~m}$ & $7.113 \mathrm{~m}$ & $29.3 \%$ & $35.5 \%$ \\
\hline 2004 & $6.424 \mathrm{~m}$ & $7.559 \mathrm{~m}$ & $7.060 \mathrm{~m}$ & $28.8 \%$ & $34.7 \%$ \\
\hline 2005 & $6.452 \mathrm{~m}$ & $7.558 \mathrm{~m}$ & $7.056 \mathrm{~m}$ & $28.6 \%$ & $34.9 \%$ \\
\hline 2006 & $6.463 \mathrm{~m}$ & $7.602 \mathrm{~m}$ & $7.022 \mathrm{~m}$ & $28.3 \%$ & $33.3 \%$ \\
\hline 2007 & $6.471 \mathrm{~m}$ & $7.627 \mathrm{~m}$ & $7.006 \mathrm{~m}$ & $28.0 \%$ & $34.6 \%$ \\
\hline 2008 & $6.538 \mathrm{~m}$ & $7.656 \mathrm{~m}$ & $6.876 \mathrm{~m}$ & $27.4 \%$ & $33.6 \%$ \\
\hline 2009 & $6.201 \mathrm{~m}$ & $7.387 \mathrm{~m}$ & $6.715 \mathrm{~m}$ & $27.4 \%$ & $32.7 \%$ \\
\hline 2010 & $6.135 \mathrm{~m}$ & $7.328 \mathrm{~m}$ & $6.532 \mathrm{~m}$ & $26.6 \%$ & $30.8 \%$ \\
\hline 2011 & $6.056 \mathrm{~m}$ & $7.261 \mathrm{~m}$ & $6.389 \mathrm{~m}$ & $26.0 \%$ & $31.2 \%$ \\
\hline
\end{tabular}

Sources: TUC, Certification Office, and Labour Force Survey (from the ONS).

Notes: The TUC has the majority of unions affiliated to it, the $\mathrm{CO}$ records unaudited membership figures from unions which have certificates of independence and the LFS is based on seasonally adjusted figures from quarterly household surveys.

\section{Collective bargaining coverage}

Table 1 also indicates that the percentage of workers whose pay is determined by collective bargaining (through a union as opposed to a non-union collective body) has al- 
so fallen significantly over the recent period. Over a longer period of time, the WERS surveys record that $70 \%$ of workers were covered by collective bargaining in 1984 , falling to 41\% by 1998 (Milward et al., 2000). Collective determination of pay through a union (amongst other forms of collective determination of term and conditions of employment) is one of the primary reasons for the membership joining and retention. But as a result of the rise of HRM, the extents of the collective bargaining per se and collective bargaining over pay in particular have declined with the rise of (individual) performance-related pay. Bearing in mind the percentage of workers whose pay is determined by collective bargaining also includes the 'free riders', this gives a stark sense in which the phenomenon of union-determined conditions of work have become enclaves in a small number of sectors of the economy and society. This decline has been sharpened by the closure of many formerly unionised workplaces in manufacturing and not offset by the relative rise in employment in the public sector from the mid1990 s to late 2000s. As such collective bargaining is almost extinct in some parts of the private sector.

This trend may strike the observer as somewhat strange given the introduction of a statutory procedure for gaining union recognition by the then Labour government in 2000. This provided a means for obtaining the right in law to collective bargain over pay, hours and pensions. However, it is a measure of the weakness of this statutory procedure (see Gall, 2012) that it has had a very limited positive impact and one that has not helped reverse the downward trend in the extent and coverage of collective bargaining. Thus, the new statutory procedure helped facilitate over three thousand new union recognition covering around $1.4 \mathrm{~m}$ workers, of which the overwhelming majority were voluntary agreements signed in the shadow of the law. But employers have been able to resist unionisation drives because there are no effective sanctions in law available against a host of substitutionist and suppressive means by which they seek to avoid and resist unionisation (Gall, 2010b, 2012). However, the decline in the extent of union recognition is also attributable to the rise of the newly established, non-union workplaces rather than through derecognition of existing workplaces. Often the demand for union representation is not present, necessitating neither substitution nor suppression. Consequently, the percentage of workplaces covered by union recognition has, according to the WERS surveys fall from 64\% in 1980 to 27\% in 2004 (Gall, 2007, p. 88).

In terms of the outcomes of collective bargaining, the union 'mark-up' or 'premium' - the positive difference between wages and conditions in unionised and nonunionised workplaces - has undergone decline. According to the Labour Force Survey on just average hourly earnings, the superiority of union members over non-union members fell from $25.9 \%$ in 1995 to $18.1 \%$ in 2011 (having previously fallen to $12.4 \%$ in 2008) (Brownlie, 2012). On a wider measure (including job controls and other nonwage effects), the union mark-up fell - according to Bryson and Gomez (2002) - from $13 \%$ in 1994 to $3 \%$ by 2001, and from $13.9 \%$ in 1994 to $5.9 \%$ in 2009 according to Bryson and Forth (2010, p. 13) in terms of adjusted wage premium. It should also be borne in mind that the percentage of GDP going to wages has fallen from $65 \%$ in 1975 to $55 \%$ in 2010. Whatever the measures and time periods, the value of being a union member has fallen and this is all the more emphasised when a) the benefits of 
union membership are accorded to non-union members within unionised workplaces because employers apply the fruits of collective bargaining wholesale to their workforces, and b) many workers join and retain membership for such benefits in a servicing-type relationship.

In tandem with the contraction in the depth and scope of collective bargaining over terms and conditions of employment - as well as over the organisation of work itself - as a result of the rise of unitarist-HRM, collective bargaining has often been marginalised and circumvented by the rise of (micro-social) partnership agreements between unions and employers. Their extent is greater than previously thought (Bacon \& Samuel, 2009), covering 10\% of workers overall and around one third of public sector workers. These procedural, rather than substantive, agreements have often (as typified by their widespread emergence in the finance sector (Gall, 2008)) seen negotiation superseded by consultation. Debate remains live on whether such consultation at an earlier stage in employer decision making processes allows greater subsequent influence, whether through negotiation or obviating the need for negotiation (see Samuel \& Bacon, 2010). The impact of partnership agreements has been to de-emphasis the significance of workplace unionism although its atrophy was already well set in train beforehand. The previous vibrant networks of inter- and intra-industry shop stewards mostly no longer exist in any meaningful way. The exceptions are a number of workplaces in the public and ex-public sector that can support strikes, especially unofficial ones.

\section{Strikes and industrial action}

Given the decline in union power within the workplace and labour market, strikes and industrial action are good indicators of unions' mobilising prowess. To these indicators need added the particular use of ballots for strike and industrial action as bargaining chips in the collective bargaining process and the prevalence of unofficial strikes which retain the element of surprise (unlike official action). Strike activity by the number of strikes has fallen continuously over the period (see Table 2) while, despite often substantial yearly fluctuations, the number of workers involved and days not worked has remained at an historical low (see also Lyddon, 2007, 2009). It was not until 1988 that the number of strikes fell below 1,000 per annum and stayed that way thereafter. It was not until 1985 that the number of workers involved fell below one million and stayed that way thereafter. And, with the exception of three years which were affected by individual strikes in the postal service and the public sector, the number of days not worked has been less than one million since 1991. Strikes are predominantly characterised by being discontinuous one-day actions and by selective groups of workers. The period of all-out, indefinite strikes has passed. Unfortunately, there is no comparable data on industrial action short of a strike (such as overtime bans and work-torules) but various surveys have recorded that it has also experienced decline and not any fillip as a result of workers seeking to deploy it as an alternative to striking given the costs and restrictions associated with strikes (Gall \& Cohen, 2013). These costs concern primarily lost income and legal requirement for lawful strike action (such as the requirements of the balloting and notification processes). 
Table 2: $\quad$ Strike activity in Britain, 1992-2010

\begin{tabular}{|c|c|c|c|c|c|c|c|}
\hline Year & $\begin{array}{l}\text { No of } \\
\text { strikes }\end{array}$ & $\begin{array}{l}\text { Workers } \\
\text { involved } \\
\text { (m) }\end{array}$ & $\begin{array}{c}\text { Days not } \\
\text { worked }(\mathrm{m})\end{array}$ & $\begin{array}{c}\text { Days not } \\
\text { worker per } \\
1,000 \text { workers }\end{array}$ & $\begin{array}{l}\% \text { strikes which } \\
\text { were unofficial }\end{array}$ & $\begin{array}{l}\% \text { all workers in- } \\
\text { volved in unofficial } \\
\text { strikes }\end{array}$ & $\begin{array}{c}\% \text { all days not } \\
\text { worked in unofficial } \\
\text { strikes }\end{array}$ \\
\hline 1992 & 253 & 0.148 & 0.528 & 23 & $40 \%$ & $19 \%$ & $9 \%$ \\
\hline 1993 & 211 & 0.385 & 0.649 & 28 & $36 \%$ & $5 \%$ & $7 \%$ \\
\hline 1994 & 205 & 0.107 & 0.278 & 12 & $48 \%$ & $48 \%$ & $32 \%$ \\
\hline 1995 & 235 & 0.174 & 0.415 & 18 & $39 \%$ & $28 \%$ & $21 \%$ \\
\hline 1996 & 244 & 0.364 & 1.303 & 55 & $47 \%$ & $9 \%$ & $4 \%$ \\
\hline 1997 & 216 & 0.130 & 0.235 & 10 & $36 \%$ & $50 \%$ & $41 \%$ \\
\hline 1998 & 166 & 0.093 & 0.282 & 11 & $49 \%$ & $51 \%$ & $58 \%$ \\
\hline 1999 & 205 & 0.141 & 0.242 & 10 & $45 \%$ & $33 \%$ & $26 \%$ \\
\hline 2000 & 212 & 0.183 & 0.499 & 20 & $80 \%$ & $20 \%$ & $17 \%$ \\
\hline 2001 & 194 & 0.183 & 0.525 & 20 & $59 \%$ & $43 \%$ & $15 \%$ \\
\hline 2002 & 146 & 0.943 & 1.320 & 51 & $38 \%$ & $3 \%$ & $4 \%$ \\
\hline 2003 & 133 & 0.151 & 0.499 & 19 & $32 \%$ & $41 \%$ & $26 \%$ \\
\hline 2004 & 130 & 0.293 & 0.905 & 34 & $36 \%$ & $3 \%$ & $1 \%$ \\
\hline 2005 & 116 & 0.093 & 0.158 & 6 & $15 \%$ & $6 \%$ & $6 \%$ \\
\hline 2006 & 158 & 0.713 & 0.755 & 28 & $15 \%$ & $1 \%$ & $2 \%$ \\
\hline 2007 & 142 & 0.745 & 1.041 & 38 & $27 \%$ & $4 \%$ & $3 \%$ \\
\hline 2008 & 144 & 0.511 & 0.759 & 28 & $8 \%$ & $0 \%$ & $1 \%$ \\
\hline 2009 & 98 & 0.209 & 0.455 & 17 & $34 \%$ & $1 \%$ & $14 \%$ \\
\hline 2010 & 92 & 0.132 & 0.365 & 14 & $17 \%$ & $2 \%$ & $1 \%$ \\
\hline
\end{tabular}

Source: Labour Market Trends/Economic and Labour Market Review and Gall \& Cohen (2013)

However, in an unexpected turn of fortune, the requirement for balloting prior to strikes and industrial action since the mid-1980s has given unions an extra weapon in their armoury. The process of notifying the employer of the intention to ballot, conducting the ballot, announcing the result and then giving notice of the action to the employer have provided unions with a means of applying increasing pressure upon employers within a bargaining context. Given that the number of ballots far exceeds the numbers of strikes and that most ballots return mandates for action, it is a reasonable assumption to make that unions have used this tool productively to gain some or all of their bargaining objectives (see Gall \& Cohen, 2013). Nonetheless, even this method has experienced a decline in frequency in recent years after reaching a highpoint of 1,000 ballots per year. Finally, the use of unofficial (or 'wildcat') strikes which do not conform to the requirements of forewarning and, thus, forearming employers - has also experienced significant decline in relative and absolute terms (see Table 1). Back in the heyday of strike activity of the 1960 s and 1970 s, some $95 \%$ of strikes were not official (i.e. largely unofficial), giving some testament to the potency of the wildcat strikes as short, sharp and powerful actions. Given that solidarity strikes 
are now unlawful, the avenue of unofficial strikes is the only means for them to be held but they are almost unheard of now.

The concentration of strikes is now largely a public sector phenomenon, testifying to higher membership densities and the maintenance of some rudimentary workplace organisation there. However, the protection from the immediacy of market mechanisms and the ability to use strikes as an appropriate form of political - rather than economic - leverage also explains this preponderance. That said, the one clear exception to this rule is that of private sector transport and communications (specifically, Royal Mail, which remains state-owned (see Gall, 2003)), where because of embedded workplace unionism, the immediate and considerable impact of strike action and the limited availability of alternatives or substitute services, strikes remain potent weapons. Cumulatively, this signifies the withering away of the private sector, economic strike. The decline in the scale of manufacturing and the intensity of competition in that which remains - along with the atrophy of membership and workplace organisation - seems to account for this withering away. This observation is made all the more stark by the manifest inability of workers (production, transport, service) and their unions to take advantage of the now highly integrated systems of just-in-time production/just-in-time delivery and contracting out to dedicated providers of services. Such systems now widely used in the production, distribution and exchange of goods and services are very fragile and sensitive, allowing pressure points to be identified for use in the collective bargaining process. The one very partial exception to this pattern of non-use has been that the Unite union has sought to ratchet up the terms and conditions of workers in supply companies by placing political pressure upon those companies which buy from the suppliers. This has been most developed in food production via the supermarkets and in the City of London regarding contract cleaning. While the progress made has been significant in these two areas, progress to attain it has been slow - certainly slower than would have been the case had the pressure of industrial action been used.

Turning to the outcomes of strikes and industrial action, the periods of advances of the 1970s and defeats of the 1980s have been replaced by action which is both less offensive on the wage front and less defensive on the jobs front but which secures minor concessions (with the exception of strikes in transport). Some defeats like the firefighters' strikes of 2002-2003 and the Scottish nursery nurses' strike of 2003-2004 have been outnumbered by those which secure minor concessions of higher pay rises than employers initially offered but less than union originally demanded. However, major strikes in the public sector continue to demonstrate that workers will join unions when they take action over manifest grievances. Nonetheless, the wider picture is not just of fewer strikes but little resistance to the scale of retrenchment in jobs and pay levels since 2007 throughout the public and private sectors. Indeed, a number of unions sponsored agreements in manufacturing to prevent job cuts by consenting to uncompensated short-time working and pay cuts and pay freezes.

\section{Changes in union politics and perspectives}

There are two key dimensions to changes in union politics (broadly defined). The first concerns union identity and the second the political perspectives of national union 
leaderships. Most unions are no longer trade unions, nor even unions of trades. The majority of union members are members of general unions which straddle both the public and private sectors. The only sizeable unions which maintain a distinctive identity are those for teachers, nurses and doctors. The decline in this form of identity has left something of a void given that it has not been replaced by new and alternative forms of identity and perspective like social movement unionism or social democratic unionism. Consequently, the cohesiveness and effectiveness of unions as collective organisations has been undermined. Since the early 2000s, the national union leadership in all the major unions (save USDAW) have been replaced by more radical and progressive ones (initially dubbed the 'awkward squad' by the media). Consequently, unions have taken a more critical perspective towards employers, capital, the state and government. This has specifically meant less support for partnership and compromise with employers as well as criticism of what is seen as an insufficiently radical Labour Party (and of which 65\% of the membership of the TUC unions are affiliated to including the biggest four unions). Throughout the years of Labour Party leadership by Tony Blair and Gordon Brown (1994-2010), the affiliated unions were unwilling to exert a united influence on the Labour Party. When they did, after years of mounting frustration, what they achieved in the form of the 'Warwick Agreement' (Mark I and Mark II) was too little, too late as Labour entered a period of protracted internally and externally induced crisis from 2005 onwards. When the affiliated unions did finally punch their collective weight by electing Ed Miliband to the Labour leadership, Labour was no longer in government and Miliband has shown himself to be insufficiently receptive (i.e. leftwing) to the unions' political agenda. For example, Labour's policy under Miliband is of fewer cuts and more slowly rather than no cuts at all. Despite all this, disaffiliation from Labour in order to support more leftwing parties has been insignificant and no sizeable left party (as in Germany, Greece or Portugal) has, thus, emerged. There is a 'chicken and egg' situation where no major unions are willing to support the creation of a new, credible leftwing political party because no new, credible leftwing political party already exists.

So, the move to the left amongst the union leaderships has, thus, not noticeably moved the situation forward for unions. Not only has the overall combativity of workers not measurably increased - judged by the strike statistics - as a result of the election of these new leaderships but the levels of participation of members in their unions - judged by voting turnouts in union elections and industrial action ballots as well as attendance at union meetings - has not improved either (see also McIlroy \& Daniels, 2009b). The partial exceptions to this tendency are the PCS civil servants and RMT transport unions. Much of this unfulfilled promise of the new, more radical leaderships may be attributed to the members that voted these leaders in wishing the leadership to fight on their behalf rather than fight themselves even if led or guided by these leaderships. For example, the continued incursion of the market into public services continues to attract widespread and searing criticism, but under both Labour (1997-2010) and Conservative dominated (2010-) governments, resistance has been limited and muted. Finally, although many of these union leaderships are supportive of social movement or community unionism, this has not led to the emergence of these forms in any significant way. The sole example which proves the rule is London 
Citizens which has secured a 'living wage' (around 50\% higher than the legal minimum wage) for many cleaners in London. The decline of the recent anti-capitalist and antiimperialist movements, along with the absence of an anti-cuts or austerity movement, again highlights the stunted nature of any moves towards social movement unionism.

\section{Summary}

The majority of unions in Britain have experienced significant disarticulation and disorganisation over the last twenty-odd years. Disarticulation refers to the quantitative state of unions while disorganisation refers to the qualitative state of unions. The few positive developments that exist are built upon weak foundations and are themselves quite frail and potentially superficial. Indeed, the overall worth of significant, forward developments by any particular union are limited by the fate of others which exert a backward pull. Clearly, this is far from a strong basis from which to contemplate much less enact - renewal and revitalisation.

\section{Prospect: prospects for renewal}

Any analysis of the prospects for renewal and revitalisation of the unions (and union movement) in their quantitative and qualitative dimensions must focus upon internal and external dimensions - in other words, the unions themselves, the environment they operate within, and the inter-relationship between both. Without significant and sustained changes in economy and society, unions are likely to experience further decline in terms of organisation and influence. Indeed, without significant changes within unions, they will be unable to take advantage of such changes in their external environment. This concluding section maps out these necessary components, showing that even standing still would be a considerable achievement. Although standing still would not in itself constitute renewal and revitalisation but it might - at best - provide the springboard for renewal and revitalisation at some point in the future.

Unions were stronger and more influential bodies when a) the economy experienced sustained growth; b) public policy and government action were relatively supportive and demonstrated in the regulation of capital; c) the largest employers were characterised by pluralist approaches to unions; d) the level of open industrial conflict was greater; and e) the political centre of gravity revolved around a limited form of social democracy where market mechanisms and outcomes were moderated by state intervention. Presently, and for the foreseeable future, the following conditions are likely to exist: a) the economy is contracting or experiencing negligible growth; b) public policy and government action continue to be agnostic at best and hostile at worst, with clear evidence of the continued regulation of the collective action of workers but not those of capital (individually or collectively); c) the majority of employers of any size are characterised by unitarist mindsets; d) notwithstanding a number of large strikes in the public sector in recent years, the level of open industrial conflict continues to decline; and e) despite the financial crash of 2007-2008 and the ensuing recession, neo-liberalism is no less powerful as an ideology of capital than it was before. Indeed, the occasion of the crash and recession has been used as an opportunity to justify and further advance the cause of neo-liberalism by ramping up the speed by 
which neo-liberal measures of deregulation and privatisation are implemented under the Conservative-Liberal Democrat coalition government of 2010 onwards.

In this situation, the hope of the unions is not of one of a new found conviction for social partnership with the government for it is seen as the 'enemy' and the 'problem'. Quite apart from the continued and hastened implementation of neo-liberalism, the Conservative-Liberal Democrat coalition is also implementing extensive cuts in public sector employment which is the heartland of the union movement. Nor is the hope of unions associated with a new found conviction for social partnership with employers because they are generally seen as not only being antagonistic towards unions as organisations but willing to reduce their levels of employment and the real value of their workers' wages to maintain levels of profitability in time of recession. Consequently, where there is any sense of idea of where a revival of unions may come from, it is from the hope of a flowering of opposition by workers revolting against their employers and citizens revolting against their government as their standards of living deteriorate under a pincer movement from both. This is the underlying perspective of Frances O'Grady and the recently elected general secretary, Len McCluskey, of the largest union, Unite. The perspective involves unions acting as tribunes for workers in general but also with other social movements and groups. Specifically, O'Grady has propounded on the need for unions to form a 'grand alliance' not just amongst themselves but with others outside itself where a coalition which unites the providers and users of public services is the foundation stone to the mobilisation of collective resistance.

But whether the collective confidence and organisation amongst workers and citizens exists to undertake this double-edged revolt is very much open to question. While demonstrations like that of 26 March 2011 against austerity and for growth have been sizeable, the willingness of unions to jointly pursue coordinated industrial action on common issues has not proven to be sizeable. The strike against public sector pension reform on 30 November 2011 by around $3 \mathrm{~m}$ workers proved to be the exception and not the rule. Sectionalism and political difference conspired against further such instances of mass striking. Presently, there is only talk of such united action against public sector pay freezes (even they have been in existence for a number of years). And, quite apart from the whether such a revolt will materialise, the other unresolved issue is what the likely outcome of the revolt would be. Again by the perspective of O'Grady and McCluskey, this would see the return of the Labour Party to office to halt and undo the cuts and austerity. However, the current Labour leadership shows no willingness or ability to adopt such an anti-cuts position, much less force an election and win it. In this situation, the strategy of O'Grady and McCluskey is found wanting, especially as neither - but especially O'Grady - seem prepared to countenance attempting to organise the kind and scale of opposition which could force the government into U-turns. The benchmarks for this were the revolts of the early 1970s, where the then Conservative was forced by unions to nationalise a number of companies, grant pay rises far in excess of what it was originally willing to do, and accept that certain pieces of legislation became 'dead letters'.

Another 'chicken and egg' situation pervades the current era in which the unions operate. One the on hand, the inability of the forces of social democracy to revive 
themselves at a time of economic, political and ideological crisis for neo-liberalism means that the stimulus of ideas to orchestrate a revolt in the industrial and political arenas that unions operate within has been notable by its absence. On the other hand, the absence of sizeable revolts based upon material or economic deprivations has not given rise to an ideological and political ferment where the ideas or forces of social democracy can take hold. The same points - but to a greater degree - can be made about the forces of socialism as well.

The particular dimension for industrial relations here is that the demise of neoliberalism and the ascendancy of social democracy in society at large would find and compel parallel developments in the governance of companies and workplaces. This would be to envisage a re-flowering of the co-determination of the terms and conditions of work and the organisation of work, whether it be through the sole channel of unions (via collective bargaining) or through works councils and supervisory board (unionised and non-unionised workers). It would also be to envisage the repeal of the anti-union legislation, dating back to the 1980s, that heavily limits and restricts what is lawful and legitimate strike and industrial action. Given the contemporary weakness of unions in the industrial relations arena, it is high unlikely that they will be able to initiate the process by which co-determination emerges from within this arena alone - unless there were to be a re-run of the kind of grassroots revolt which took place in the late 1960s and early 1970s. Under those conditions, not only would workers and unions be stronger but employers would no doubt see the institution of codetermination as a way to prevent workers' encroaching control becoming unilateral control. That is not to suggest that developments in the industrial relations arena are far from insignificant but that they would need to be part of - and constitute - a wider societal process to be effective agents of change. Such a perspective at the very least suggests that continued and further investment in the main response of unions to their decline - 'union organising' - is inadequate to address the depth and breadth of the challenges they face to reassert themselves.

\section{Conclusion}

Turning back and reversing the rising tide of neo-liberalism in society and economy and its sibling HRM in the workplace - is clearly a task beyond the power and ability of any one individual in the union movement (such as Frances O'Grady). The use of such a proposition was, thus, essentially heuristic in that it demonstrated that leaders and leadership on their own are incapable of bringing about - even facilitating - widespread and deep-seated radical change which is favourable to workers and their unions. Indeed, the proposition was heuristically helpful in exploring the kind of requisite mobilised social forces (union leaders, union members, workers) and their interrelationship in regard of bringing about such change. Even when leaders are seen as a small cog that can attempt to turn the larger cog of members and produce collective actions, the direction of travel is not simply from leaders to members. The example of the Organising Academy indicates the extent to which leaders are dependent upon followers to follow and be lead. Indeed, if the cog of members cannot be turned by the leadership, then the leadership cog becomes itself static and immobilised. For O'Grady, any attempt to bring about renewal will have to be from an ever more de- 
pleted base for TUC affiliated membership fell just below six million $(5.977 \mathrm{~m})$ for the first time in a generation in 2012.

If there is something of a salvation for the union movement in its goal to achieve renewal and revitalisation, it is to be recalled that the upturn in the previous fortunes of unions are often heavily associated with the upswing of class struggle - especially based around and reflected in strikes and industrial conflict (Kelly, 1998). The rise of 'new unionism' in the 1880s and the developments of the first and second shop stewards movement in the twentieth century are such examples. Retrospective analysis has been able to identify the conditions and actors that gave rise to such phenomena but prospective analysis is more difficult, other than in the most general terms. This highlights certain combinations of environment and agency, at least indicating that such future change is possible if not entirely probable. To this end, unions presently remain more on the margins than on the cusp of a comeback. It should not, thus, be assumed that the worsening of economic and social conditions in the wake of the crisis of neoliberalism and the crisis in capitalism since 2008 necessarily and mechanically could or would mean that unions are to be revitalised and renewed.

Setting this conclusion in the context of the main strands of academic perspectives on the renewal of unions and the rights of workers demonstrates a case of unmet desires and unfulfilled potential. The debate over (social) partnership of the microkind with employers and the macro-kind with government and state (see, for example, Ackers \& Payne, 1998) versus the deployment of militancy in bargaining with employers and government/state (see, for example, Kelly, 1996) has found that subsequent practice neither validated nor invalidated each perspective. For example, while partnership received political support from government, some employers and some unions, it never achieved lift off. Whether this was due to lack of legal underpinning and scarcity of resource to allow implementation is open to some debate. But what is less open to debate is that the time for partnership in Britain has passed for the time being as the bases of economic growth and government support no longer exist. Militancy has never been given a fair crack of the whip for few unions (bar the PCS and RMT) can be said to have consistently attempted to work on the basis of ambitious demands enforced by widespread collective mobilisation. Consequently, it would be rather premature to attempt to provide an answer - let alone a definitive one - on whether militancy is a viable modus operandi. The other major academic perspective of institutionalising workers' collective rights in law (see, for example, Ewing, 2001, 2005) is a far cry from the advocacy of free collective bargaining, unhindered and unencumbered by legal regulation. The move from the one to the other reflects the erosion of union power. Here again, it is difficult to judge whether such a strategy would deliver its objectives given that the political situation has never allowed the legislation to be passed that would facilitate making this judgement.

Finally, what more general lessons does the plight of the union movement in Britain offer unions in other countries? Although the result of these actions is yet to be fully understood because of their recent nature and the continuing unfolding of the economic crisis, widespread collective mobilisations in many southern European countries (especially in the form of the general strike - a mass political strike) do suggest that extant unions can blunt - if not stop and reverse - austerity programmes to 
some degree. Here, there is more of a sense that the advocacy of militancy abroad may have something to teach unions in Britain. This is especially so as the 2012 annual conference of the TUC voted to mandate the TUC bureaucracy to investigate the legal and logistical challenges of holding a general strike against the austerity measures. Given that the only (actual as opposed to planned) general strike in Britain took place in 1926, this does serve to indicate that the union movement is at least looking at new ways of dealing with pressing problems. If such a strike was to go ahead, a greater assessment of the fruits of militancy could be made.

\section{References}

Ackers, P., \& Payne, J. (1998). British trade unions and social partnership: Rhetoric, reality and strategy. The International Journal of Human Resource Management, 9(3), 529-550.

Bacon, N., \& Samuel, P. (2009). Partnership agreement adoption and survival in the British private and public sectors. Work, Employment and Society, 23(2), 231-248.

Batstone, E. (1988). The frontier of control. In D. Gallie (Ed.), Employment in Britain (pp. 218-247). Blackwell, Oxford,.

Brownlie, N. (2012). Trade union membership 2011. Department for Business, Innovation and Skills, London.

Bryson, A., \& Forth, J. (2010). Trade union membership and influence, 1999-2009. National Institute of Economic and Social Research, London.

Bryson, A., \& Gomez, R. (2002). Marching on together? Recent trends in union membership. In A. Park, J. Curtice, K. Thomson, L. Jarvis, \& C. Bromley (Eds.), British social attitudes: the 19th report (pp. 4367). London, Sage.

Cochrane, K. (2012). TUC leader Frances O'Grady: People want some hope for the future. Guardian, 6 September.

Daniels, G. (2009). In the field: a decade of organizing. In G. Daniels, \& J. McIlroy (Eds.), Trade unions in a neoliberal world: British trade unions under New Labour (pp. 254-282). Abingdon, Routledge,.

Ewing, K. (2001). Trade union rights in the twenty first century. Working USA, 5(1), 19-43.

Ewing, K. (2005). The Function of Trade Unions. In Industrial Law Journal, 34(1): 1-22.

Gall, G. (2003). The meaning of militancy? Postal workers and industrial relations. Aldershot, Ashgate.

Gall, G. (2005). Trade unions: Back from the brink or still on the margins? International Socialism Journal, 105, 98-111.

Gall, G. (2008). Labour unionism in the financial services sector: Struggling for rights and representation. Aldershot, Ashgate.

Gall, G. (2007). Trade union recognition in Britain: A crisis of union capacity? Economic and Industrial Democracy, 28(1), 83-114.

Gall, G. (2010a). Closing down a means of collective voice for workers - victimisation of union activists in Britain. Journal of Workplace Rights, 14(1), 75-95.

Gall, G. (2010b). 'Union Organising' and the health of the union movement in Britain. Institute of Employment Rights, London.

Gall, G. (2012). Union recognition in Britain: The end of legally-induced voluntarism?' Industrial Law Journal, 41(4), in print

Gall, G., \& Cohen, S. (2013). The collective expression of workplace grievances in Britain. In G. Gall (Ed.), New forms and expressions of conflict at work. Basingstoke, Palgrave.

Gall, G., \& Fiorito, J. (2011). The forward march of labour halted? Or what is to be done with 'union organising'? The cases of Britain and the US. Capital and Class, 35(2), 231-250.

Kelly, J. (1996). Union militancy and social partnership. In P. Ackers, C. Smith, \& P. Smith (Eds.), The new workplace and trade unionism: Critical perspectives on work and organization (pp. 77-109). Routledge, London. 
Kelly, J. (1998). Rethinking industrial relations: Collectivism, mobilisation and long waves. London, Routledge.

Lyddon, D. (2007). From strive wave to strike drought: the United Kingdom, 1968-2005. In S. van der Helden, H. Dribbusch, D. Lyddon, \& K. Vandaele (Eds.), Strikes around the world, 1968-2005: case studies of 15 countries (pp. 339-365). Amsterdam, Aksant.

Lyddon, D. (2009). Strikes: Industrial conflict under New Labour. In G. Daniels, \& J. McIlroy. (Eds.), Trade unions in a neoliberal world: British trade unions under New Labour (pp. 316-341). Abingdon, Routledge.

McIlroy, J., \& Daniels, G. (2009a). An anatomy of British trade unionism since 1997: Strategies for revitalisation. In G. Daniels, \& J. McIlroy (Eds.), Trade unions in a neoliberal world: British trade unions under New Labour (pp. 98-126). Abingdon, Routledge.

McIlroy, J., \& Daniels, G. (2009b). An anatomy of British trade unionism since 1997: organization, structure and factionalism. In G. Daniels, \& J. McIlroy (Eds.), Trade unions in a neoliberal world: British trade unions under New Labour (pp. 127-164). Abingdon, Routledge.

Milward, N., Bryson, A., \& Forth, J. (2000). All change at work? Routledge, London,

Samuel, P., \& Bacon, N. (2010). The contents of partnership agreements in Britain, 1990-2007. Work, Employment and Society, 24(3), 1-19.

Roberts, Y. (2012). The women changing Britain's unions. Observer, 5 August.

Upchurch, M. (2009). Partnership: New Labour's third way? In G. Daniels, \& J. McIlroy (Eds.), Trade unions in a neoliberal world: British trade unions under New Labour (pp. 230-253). Abingdon, Routledge. 